\title{
Treatment outcome and prognostic factors in PCNSL
}

\author{
Pimjai Niparuck ${ }^{1 *}$, Paisarn Boonsakan², Taksayut Sutthippingkiat', Sulada Pukiat ${ }^{1}$, Pichika Chantrathammachart ${ }^{1}$, \\ Sithakom Phusanti ${ }^{1,3}$, Kochawan Boonyawat ${ }^{1}$, Teeraya Puavilai ${ }^{1}$, Pantep Angchaisuksiri ${ }^{1}$, Artit Ungkanont ${ }^{1,3}$, \\ Suporn Chuncharunee ${ }^{1}$ and Vichai Atichartakarn ${ }^{1}$
}

\begin{abstract}
Objectives: Standard treatment with a thiotepa-based regimen in countries with a limited resource is less feasible. Aims of the study were to evaluate the treatment outcome, and identify the prognostic factors in patients with primary central nervous system lymphoma (PCNSL).

Methods: We conducted a retrospective study of 43 patients diagnosed with PCNSL, DLBCL subtype, who were treated with either HDMTX-based regimen, whole brain radiotherapy (WBRT), or both between 2010 and 2017.

Results: There were 43 patients with a median age of 65 years (range 34-89 years). Protein expression of CD10, Bcl6, MUM1, BCl2 and MYC were found in 19,86, 91, 91 and 23\%, respectively. Both germinal center B cell (GCB) and double-expressor (MYC+/BCl2+) lymphomas were found in 21\%. Multiple brain lesions and maximum tumor diameter (MTD) $\geq 5 \mathrm{~cm}$ were seen in 27 and 10 patients, respectively. Chemotherapy combined with WBRT, chemotherapy and WBRT were given to 20, 14 and 9 patients, respectively. Overall complete remission (CR) rate was 55.8\%. Those receiving a combined-modality therapy had a higher CR rate than those treated with either chemotherapy $(75 \%$ versus $36 \%, p=0.036$ ) or WBRT (75\% versus 44\%, $p=0.109$ ). Median follow-up time was 17 months, and a 7 -year overall survival (OS) was $40 \%$. Features associated with a prolonged OS were an ECOG score $\leq 2(p=0.001)$, multiple brain lesions $(p=0.010)$, multiple area of brain involvement $(p=0.023)$, MTD $<5 \mathrm{~cm}$ $(p=0.004)$, GCB subtype $(p=0.003)$ and positive CD10 staining $(p=0.007)$. Expression of $\mathrm{Bc} 12$ protein was associated with a significantly worse OS in the non-GCB DLBCL patients.
\end{abstract}

Discussion: The factors affecting treatment outcomes in PCNSL were cell of origin of DLBCL, lesion characteristics, patients' status and treatment regimen.

Keywords: PCNSL, Chemotherapy plus WBRT, GCB lymphoma, Non GCB lymphomas, CD10

\section{Introduction}

Primary central nervous system lymphoma (PCNSL) is an uncommon type of lymphoma, and has a dismal survival rate. It constitutes approximately $2-3 \%$ of nonHodgkin's lymphoma (NHL) cases, and non-GerminalCenter B cell (non-GCB) subtype of diffuse large B cell lymphoma (DLBCL) is the most common histopathology [1-4]. Prognostic features as proposed by the International Extra-nodal Lymphoma Study Group (IELSG) include age, Eastern Co-operative Oncology Group

\footnotetext{
*Correspondence: niparuckblue@gmail.com

'Division of Hematology, Department of Medicine, Ramathibodi Hospital, Mahidol University, Bangkok, Thailand

Full list of author information is available at the end of the article
}

(ECOG) performance status score, serum lactate dehydrogenase (LDH) level, cerebrospinal fluid (CSF) protein concentration and involvement of deep structure of the brain $[5,6]$. Treatment with chemotherapy and whole brain radiotherapy (WBRT) has a better survival rate than those treated with either modality alone. However, neurological toxicity was found in those receiving a combined-modality therapy after a long term follow-up [7-11]. The current chemotherapy for PCNSL is a high dose methotrexate (HD-MTX) based regimen, or a HDMTX in combination with a high dose cytarabine. Addition of thiotepa and rituximab to MTX/cytarabine (MATRix regimen) increases the overall response (OR) and complete remission (CR) rates [12]. The progression

(c) The Author(s). 2019 Open Access This article is distributed under the terms of the Creative Commons Attribution 4.0 International License (http://creativecommons.org/licenses/by/4.0/), which permits unrestricted use, distribution, and 
free (PFS) and the overall survival (OS) rates also increase after consolidation with an autologous hematopoietic stem cell transplantation (Auto-HSCT) or WBRT in those treated with MATRix regimen compared to those receiving only MTX/cytarabine [13]. However, treatment with a thiotepa-based regimen in countries with a limited resource is difficult to implement. We, therefore, conducted a retrospective study of newly diagnosed PCNSL patients with a DLBCL subtype, who had received a HD-MTX-based chemotherapy, WBRT, or both for the treatment outcome and prognostic factors.

\section{Materials and methods \\ Patients}

Forty- three adult patients with a newly diagnosed PCNSL of DLBCL subtype at our hospital between May 2010 and May 2017 were analyzed. All histo-pathological and immuno-histochemical (IHC) slides were reviewed. The diagnosis of DLBCL was confirmed by an experienced hemato-pathologist, who categorized them by the Han's algorithm [4, 14]. This subtype with MYC ( $\geq 40 \%)$ and $\mathrm{Bcl} 2(\geq 50 \%)$ co-expression was classified as doubleexpressor lymphoma (DEL) [15]. CD10, Bcl6 and MUM1 staining were considered positive when expressed in at least $30 \%$ of tumor cells. Characteristics of the brain lesion including number, area, sizes and leptomeningeal involvement were done by magnetic resonance imaging (MRI). Staging evaluation with computer tomogram of the chest and abdomen, and bone marrow biopsy were done in all patients. Excluded from analysis were those with the following features:- < 18 years old, positive serology for human immunodeficiency virus (HIV), secondary CNS lymphoma, post hematopoietic stem cell transplantation (HSCT) and treatment refusal.

\section{Study design and end points Treatment protocol and evaluation}

Fit patients aged $\leq 60$ years old were treated with a HDMTX $\left(2-3 \mathrm{~g} / \mathrm{m}^{2}\right)$ on day 1 and cytarabine $2 \mathrm{~g} / \mathrm{m}^{2}$ every 12 h on days 2 and 3 , while those aged $>60-65$ years received a reduced cytarabine dose at $1 \mathrm{~g} / \mathrm{m}^{2}$. Those aged $>65$ years or unfit received only HD-MTX at $1-2 \mathrm{~g} / \mathrm{m}^{2}$ on day 1 or WBRT. The chemotherapy was repeated every $2-3$ weeks in the HD-MTX group, and every 3-4 weeks in the HDMTX plus cytarabine one. Six and 3-4 cycles of chemotherapy were given to those receiving chemotherapy and a combined-modality therapy, respectively. Forty five and 36 Grey (Gy) of WBRT were given during 2010-2013 and 2014-2017, respectively. In those treated with combinedmodality, they were given after completion of the planned chemotherapy. MRI of the brain was repeated after $3 \mathrm{cy}-$ cles of chemotherapy and after completion of all treatment plans.

\section{Primary end points}

The objectives of the study were to analyze rates of relapse-free survival (RFS) and OS. A relapse-free survival was defined as the duration between date of $C R$ and first relapse. An overall survival was defined as the duration between date of diagnosis and death.

\section{Secondary end points}

To evaluate the OR and CR rates, and identify factors which affect $C R$ and survival. The overall response rate (ORR) was defined as percentage of patients with partial (reduction in tumor size $>50 \%$ ) and complete remission in the whole group.

\section{Statistical analysis}

Age, gender, number size and area of brain lesion, serum LDH level and treatment regimen of patients with and without CR were compared using a Chisquare test. Kaplan-Meier and the log-rank test methods were performed for OS, RFS analysis and difference between groups (univariate analysis). Cox's regression model was applied for a multivariate survival analysis. The SPSS statistics version 17 (Chicago: SPSS Inc.; 2008) was utilized for all data analysis. $P<0.05$ was considered significant.

\section{Results}

Patients' characteristics and results of brain tissue pathology are shown in Tables 1 and 2, respectively. There were 43 patients with a median age of 65 years (range, 34-89 years), 24 of whom were male. Twenty three patients $(53.5 \%)$ had an ECOG score $>2$. Twenty seven $(62.8 \%)$ and 31 patients (72\%) had multiple brain lesions ( $\geq 2$ lesions in one or more areas of brain involvement) and deep structure involvement, respectively. Ten patients $(23.3 \%)$ had a maximum tumor diameter (MTD) $\geq 5 \mathrm{~cm}$ (median $3 \mathrm{~cm}$ and range $1-7.1 \mathrm{~cm}$ ). A significantly larger tumor $(\geq 5 \mathrm{~cm})$ was observed in patients with solitary lesion (7/16 patients), compared to those with multiple ones $(3 / 27$ patients) $(p=0.014)$. MRI of the brain showed concurrent intra-ocular and leptomeningeal involvement in 1 and 2 patients, respectively. Serum LDH levels at diagnosis were recorded in 38 patients, $66 \%$ of whom had a normal value.

Positive staining for CD10, Bcl6, MUM1, Bcl2 and MYC were found in 19, 86, 91, 91 and 23\%, respectively. GCB subtype was found in 9 patients (21\%), 8 of whom were $\mathrm{CD} 10+(\mathrm{CD} 10+/ \mathrm{Bcl6}+/ \mathrm{MUM} 1+)$ and 1 was Bcl6+/ MUM1-. Eight GCB patients with CD10+ staining had two characteristic patterns of brain involvement; 6 had more than 1 area of involvement (2-3 areas) with the largest tumor diameter $\geq 2 \mathrm{~cm}$, and the remaining 2 patients had solitary lesion in one area of involvement with the largest tumor diameter $<2 \mathrm{~cm}$. One patients with 
Table 1 Patients' characteristics and treatment outcomes in 43 adult patients with PCNSL

\begin{tabular}{|c|c|c|c|c|c|c|c|c|}
\hline Factor & ORR N (\%) & $P$ & CR N (\%) & $P$ & Median RFS (Mo) & $P$ & Median OS (Mo) & $P$ \\
\hline \multicolumn{9}{|l|}{ Age (years) } \\
\hline$-<60$ & 10/12 (83) & 0.966 & 4/12 (33) & 0.065 & NR & 0.837 & 15 & 0.347 \\
\hline$-\geq 60$ & 26/31 (84) & & 20/31 (65) & & NR & & 17 & \\
\hline \multicolumn{9}{|l|}{ ECOG score } \\
\hline$-0-2$ & $18 / 20(90)$ & 0.298 & $15 / 20(75)$ & 0.018 & $N R$ & 0.820 & NR & 0.001 \\
\hline$-3-4$ & 18/23 (78) & & 9/23 (39) & & NR & & 13 & \\
\hline \multicolumn{9}{|l|}{ Brain lesion } \\
\hline - Single & $13 / 16(81)$ & 0.735 & $5 / 16(31)$ & 0.013 & NR & 0.456 & 9 & 0.010 \\
\hline - Multiple ( $\geq 2$ ) & 23/27 (85) & & 19/27 (70) & & NR & & 26 & \\
\hline \multicolumn{9}{|l|}{ Area of brain involvement } \\
\hline - Single & $12 / 15(80)$ & 0.629 & 4/15 (27) & 0.005 & NR & 0.900 & 10 & 0.023 \\
\hline - Multiple ( $\geq 2$ ) & $24 / 28(86)$ & & 20/28 (71) & & $N R$ & & 26 & \\
\hline \multicolumn{9}{|l|}{ Deep structure involvement } \\
\hline - Yes & 25/31 (81) & 0.380 & 18/31 (58) & 0.633 & NR & 0.141 & 26 & 0.203 \\
\hline - No & $11 / 12(92)$ & & $6 / 12(50)$ & & 10 & & 12 & \\
\hline \multicolumn{9}{|l|}{ Maximum tumor size } \\
\hline$-<3 \mathrm{~cm}$ & $14 / 17(82)$ & 0.844 & 10/17 (59) & 0.748 & NR & 0.850 & NR & 0.103 \\
\hline$-\geq 3 \mathrm{~cm}$ & $22 / 26(85)$ & & $14 / 26(54)$ & & NR & & 13 & \\
\hline \multicolumn{9}{|l|}{ Maximum tumor size } \\
\hline$-<5 \mathrm{~cm}$ & 29/33 (88) & 0.180 & 20/33 (61) & 0.250 & NR & 0.217 & 26 & 0.004 \\
\hline$-\geq 5 \mathrm{~cm}$ & $7 / 10(70)$ & & $4 / 10(40)$ & & 7 & & 8 & \\
\hline \multicolumn{9}{|l|}{ Treatment } \\
\hline - Chemotherapy (CMT) & $12 / 14(86)$ & 0.028 & $5 / 14(36)$ & 0.056 & NR & 0.663 & 17 & 0.259 \\
\hline - Radiotherapy (RT) & $5 / 9(56)$ & & 4/9 (44) & & $N R$ & & 13 & \\
\hline - CMT + RT & $19 / 20(95)$ & & $15 / 20(75)$ & & NR & & NR & \\
\hline \multicolumn{9}{|l|}{ Treatment } \\
\hline - CMT + RT & $19 / 20(95)$ & 0.062 & $15 / 20(75)$ & 0.018 & NR & 0.845 & NR & 0.231 \\
\hline - Single therapy (CMT or RT) & $17 / 23(74)$ & & 9/23 (39) & & NR & & 14 & \\
\hline \multicolumn{9}{|l|}{ LDH } \\
\hline - Normal & 22/25 (88) & 0.681 & $16 / 25(64)$ & 0.544 & NR & 0.788 & 17 & 0.876 \\
\hline - High & $12 / 13(92)$ & & $7 / 13$ (54) & & $N R$ & & 15 & \\
\hline
\end{tabular}

Abbreviations: ECOG Eastern Co-operative Oncology Group, LDH lactate dehydrogenase, ORR overall response rate, CR complete remission rate, PFS progression free survival, $O S$ overall survival, NR not reached

Bcl6+/MUM1- had 4 areas of involvement with the largest tumor diameter $<1.5 \mathrm{~cm}$. Deep structure involvement was found in 8 out of 9 GCB patients. In 34 patients (79\%) with a non-GCB subtype, Bcl6+/MUM1+, Bcl6-/MUM1+ and Bcl6-/MUM1- were found in 65\% (28/43), 7\% (3/43) and 7\% (3/43), respectively. Doubleexpressor lymphoma and double-expressor with positive Bcl6 staining were observed in 9 (21\%) and 8 (19\%) patients, respectively, and all of whom were found in nonGCB subtype. Thirty four patients (79\%) had a triple protein expression of $\mathrm{Bcl} 6, \mathrm{Bcl} 2$ and MUM1. In non GCB patients, 21 (62\%), 23 (68\%), 24 (71\%) and 9 (26\%) patients had multiple area of involvement, deep structure involvement, the largest tumor diameter $\geq 3$ and $\geq 5 \mathrm{~cm}$, respectively.

A combined-modality therapy, chemotherapy and WBRT were given to 20 (46.5\%), 14 (32.6\%) and 9 (21\%) patients, respectively. Patients' characteristics of these 3 groups, incidentally, are not statistically different. Fourteen of the twenty patients (70\%) treated with a combined-modality received a HD-MTX plus cytarabine, while the remaining 6 (30\%) received only a HD-MTX. In the chemotherapy alone group, a HD-MTX and a HD-MTX/cytarabine were given in 8 (57\%) and 6 (43\%) patients, respectively. Only 3 patients received rituximab, 2 and 1 in the chemo- and the combined-modality 
Table 2 The immuno-histochemical findings and treatment outcomes in 43 adult patients with PCNSL

\begin{tabular}{|c|c|c|c|c|c|c|c|c|}
\hline Factor & ORRN (\%) & $P$ & CRN (\%) & $P$ & Median RFS (Mo) & $P$ & Median OS (Mo) & $P$ \\
\hline \multicolumn{9}{|l|}{ Subtype of DLBCL } \\
\hline$-G C B$ & 8/9 (89) & 0.637 & 7/9 (78) & 0.136 & NR & 0.985 & NR & 0.003 \\
\hline - Non GCB & 28/34 (82) & & $17 / 34(50)$ & & NR & & 14 & \\
\hline \multicolumn{9}{|l|}{ BCL6 } \\
\hline - Positive & 30/37 (81) & 0.244 & 19/37 (51) & 0.143 & NR & 0.842 & 17 & 0.534 \\
\hline - Negative & 6/6 (100) & & 5/6 (83) & & NR & & 12 & \\
\hline \multicolumn{9}{|l|}{ Non GCB } \\
\hline - Positive MUM1 & 25/31 (81) & 0.401 & $14 / 31(45)$ & 0.070 & NR & 0.323 & 14 & 0.290 \\
\hline - Negative MUM1 & $3 / 3(100)$ & & $3 / 3(100)$ & & NR & & NR & \\
\hline \multicolumn{9}{|l|}{$\mathrm{BCL} 2$} \\
\hline - Positive & $32 / 39(82)$ & 0.354 & 21/39 (54) & 0.417 & 17 & 0.075 & 15 & 0.271 \\
\hline - Negative & 4/4 (100) & & $3 / 4(75)$ & & NR & & NR & \\
\hline $\mathrm{BCL} 2+$ in $\mathrm{GCB}$ & 5/6 (83) & 0.710 & $4 / 6(67)$ & 0.368 & NR & 0.255 & NR & 0.061 \\
\hline $\mathrm{BCL} 2+$ in non $\mathrm{GCB}$ & 27/33 (82) & & $17 / 33(52)$ & & NR & & 14 & \\
\hline \multicolumn{9}{|l|}{ MYC $\geq 40 \%$} \\
\hline - Yes & $10 / 10(100)$ & 0.111 & $6 / 10(60)$ & 0.761 & NR & 0.628 & 17 & 0.896 \\
\hline$-\mathrm{No}$ & 26/33 (79) & & 18/33 (55) & & NR & & 15 & \\
\hline \multicolumn{9}{|l|}{ Double-expressor } \\
\hline - Yes & 9/9 (100) & 0.137 & $5 / 9(56)$ & 0.986 & NR & 0.628 & 14 & 0.834 \\
\hline$-\mathrm{No}$ & 27/34 (79) & & 19/34 (56) & & NR & & 17 & \\
\hline \multicolumn{9}{|l|}{ Double-expressor } \\
\hline - BCL6+ & 8/8 (100) & 0.167 & $4 / 8(50)$ & 0.714 & 11 & 0.374 & 14 & 0.503 \\
\hline - BCL6- & 28/35 (80) & & 20/35 (57) & & NR & & 17 & \\
\hline \multicolumn{9}{|l|}{ Ki67 $\geq 80 \%$} \\
\hline - Yes & 27/33 (82) & 0.539 & 18/33 (55) & 0.761 & NR & 0.790 & 17 & 0.897 \\
\hline - No & 9/10 (90) & & $6 / 10(60)$ & & NR & & 14 & \\
\hline
\end{tabular}

Abbreviations: GCB germinal center B cell, ORR overall response rate, $C R$ complete remission rate, PFS progression free survival, $O S$ overall survival, NR not reached

therapy group, respectively. The ORR of the combinedmodality therapy group was $95 \%$, which was higher than those of the others, the chemotherapy being $86 \%$ ( $p=$ $0.383)$ and WBRT being $56 \%(p=0.009)$. Overall CR rate was $57 \%$ and was better in patients receiving a combinedmodality therapy $(75 \%)$ when compared to those treated with only chemotherapy $(36 \%, p=0.036)$ or WBRT $(44 \%$, $p=0.109$ ). In a univariate and multivariate analyses, a combined-modality therapy $(p=0.018)$, ECOG score $>2$ $(p=0.018)$, number of brain lesion $\geq 2(p=0.013)$ and number of area of brain involvement $\geq 2(p=0.005)$ significantly affected the $\mathrm{CR}$ rate. The median follow-up time was 17 months, and the $7 y$-OS and RFS were 40 and $70 \%$, respectively. Twenty four patients were dead, 18 of whom from a progressive disease, while the remaining 4 and 2 from infection and neurotoxicity, respectively. The median OS has not been reached in patients treated with the combined-modality, while it was 17 and 13 months ( $p=$ $0.259)$, respectively, in those treated with either chemotherapy or WBRT. The 2y-RFS in patients treated with the combined-modality, chemotherapy and WBRT were 78,67 and $50 \%$, respectively $(p=0.663)$. Factors associated with a prolonged OS in the univariate analysis were an ECOG score $\leq 2(p=0.001)$, a multiple brain lesions $(p=$ $0.010)$, a multiple area of brain involvement $(p=0.023)$, a MTD $<5 \mathrm{~cm}(p=0.004)$, a GCB subtype $(p=0.003)$, a positive $\mathrm{CD} 10$ staining $(p=0.007)$, and a Bcl $2+$ in $\mathrm{GCB}$ or Bcl2- DLBCL $(p=0.041)$. However, only an ECOG score $\leq$ $2(p=0.010)$ and a MTD $<5 \mathrm{~cm}(p=0.011)$ were significantly associated with a better OS in the multivariate analysis. A Bcl6-/MUM1+ DLBCL and a Bcl2+/Bcl6 -/MUM1+ DLBCL had a significantly shorter RFS. (Table 2) The survival curves are shown in Fig. 1 and 2. There was no statistically significant difference in survival between cases with myc less than or greater than $40 \%$ nor ki67 less than orgreater than $80 \%$. Delayed neurotoxicity complication (14 and 18 months, respectivelyafter WBRT) was found in 2 out of $20(10 \%)$ in the combined-modality group, with one each receiving $45 \mathrm{~Gy}$ and $36 \mathrm{~Gy}$ of WBRT, respectively. 


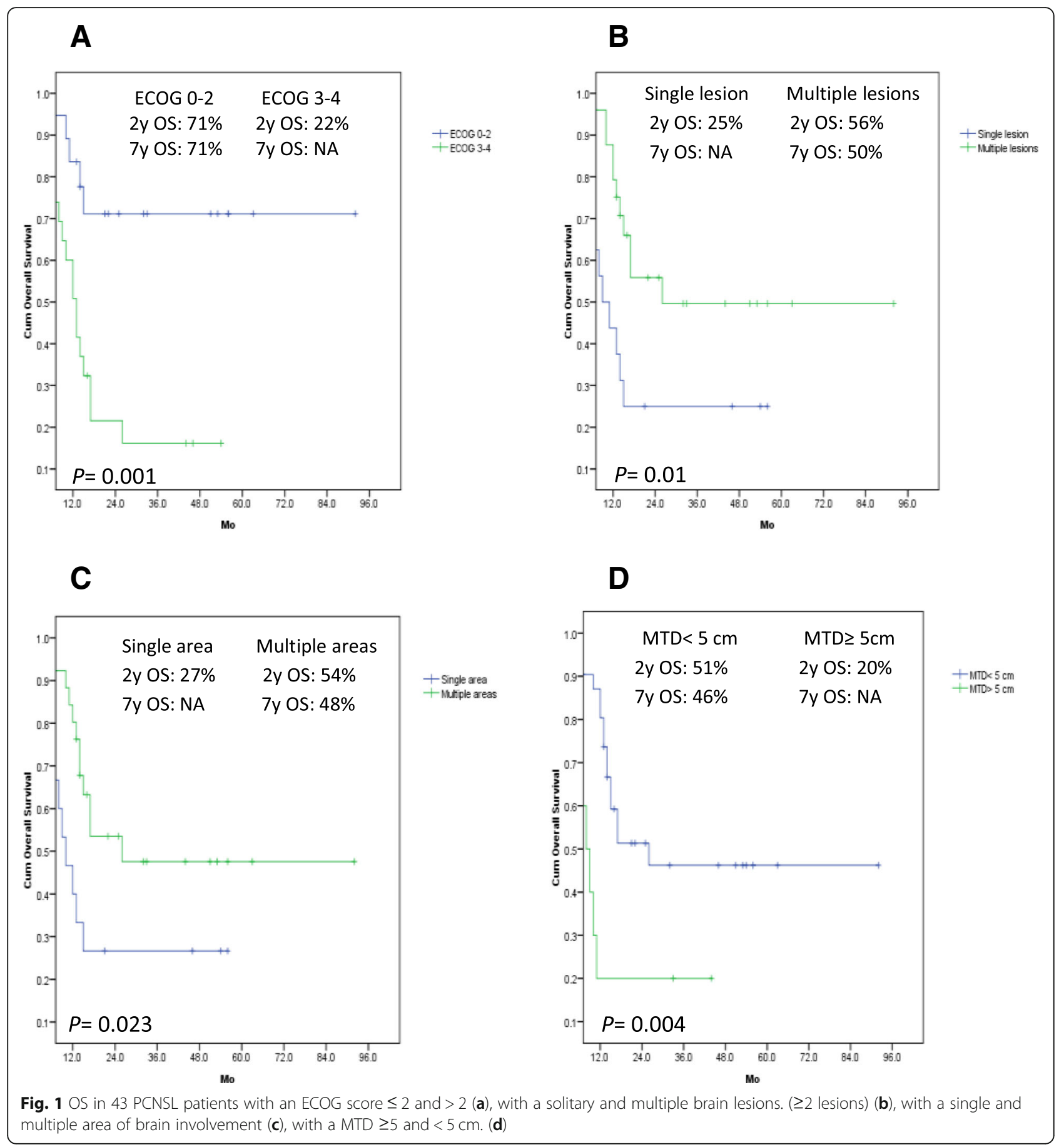

\section{Discussion}

Our study showed that both chemotherapy and chemotherapy combined with WBRT induced a high response rate (ORR $=86$ and 95\%, respectively). However, the improved CR rate (75\%) was found only in those treated with a combined-modality one, similar to that reported by the International Extra-nodal Lymphoma Study
Group-32 (IELSG-32), which showed a low CR rate after treating with 4 cycles of either HDMTX/Cytarabine (23\%) or MATRix (49\%) regimen. However, adding a 36 Gy of WBRT after MATRix increased the CR rate to 95\% [13]. A non-statistically different $(p=0.109)$, CR rate between those receiving a combined-modality therapy $(75 \%)$ and WBRT $(44 \%)$ in our study was later 
A

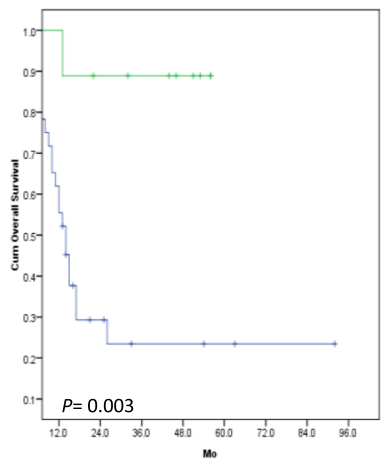

$\mathrm{GCB}$

2y OS: $89 \%$

Non GCB

7y OS: NA

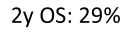

7y OS: $24 \%$

C

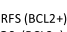

OS $(B C L 2+)$
$-R E S(B C 12-)$

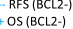

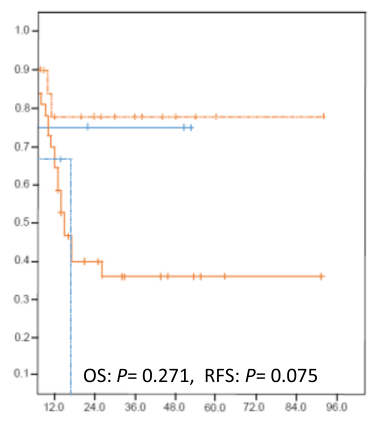

$\mathrm{BCL} 2+$ 2y RFS: $78 \% \quad 2 y$ OS: $40 \% \quad 2 y$ RFS: $0 \% \quad 2$ y OS: $75 \%$ 7y RFS: $78 \%$ 7y OS: $36 \%$ 7y RFS: $0 \%$ 7y OS: NA

E

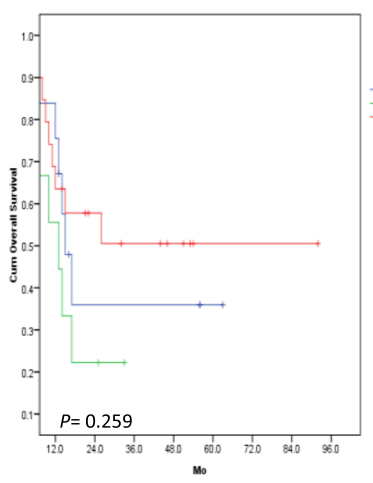

Chemotherapy WBRT Combination 2y OS: $36 \% \quad 2$ O OS: $22 \% \quad 2$ y OS: $58 \%$ 7y OS: NA 7y OS: NA 7y OS: $51 \%$
B

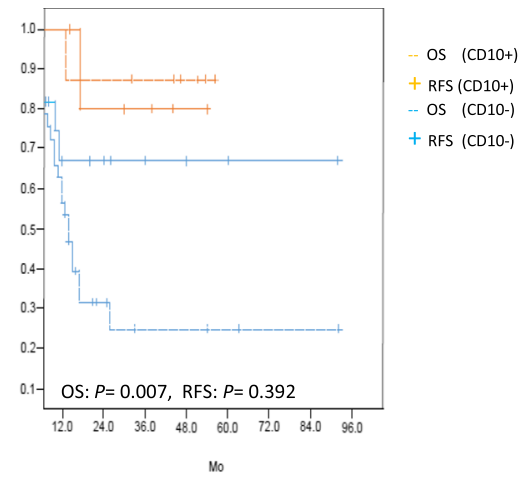

CD10+

2y OS: $88 \%$ 2y RFS: $80 \%$ 7y OS: NA 7y RFS: NA

CD10-

$2 y$ OS: $32 \%$ 2y RFS: $67 \%$ 7y OS: $25 \%$ 7y RFS: $67 \%$

D

RFS (BCL2+ in $G C B)$

RFS $(B C L 2+$ in non $G C B)$
OS $(B C L 2+$ in non $G C B)$

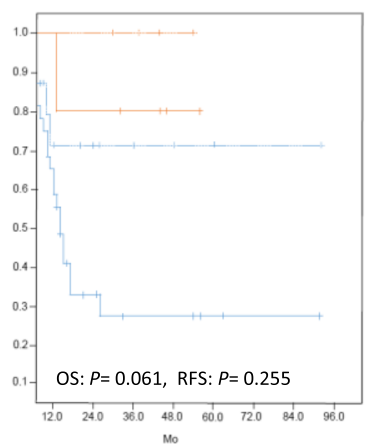

$\mathrm{BCL} 2+$ in $\mathrm{GCB}$$$
10
$$

2y RFS: $100 \%$ BCL2+ in non GCB

7yRFS: NA 7yOS: NA $\quad$ 7yRFS: $71 \%$ 2y OS: $33 \%$

\section{$\mathbf{F}$}

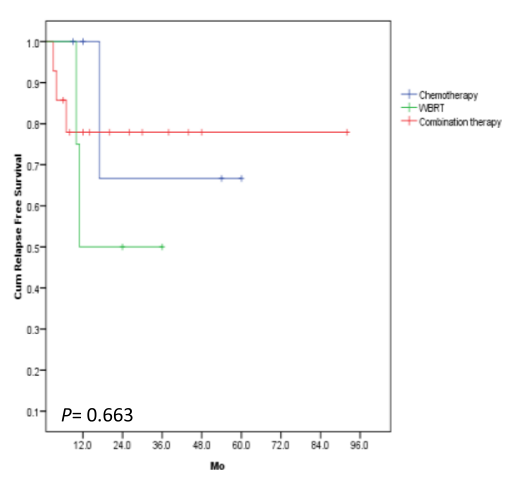

\begin{tabular}{ccc} 
Chemotherapy & \multicolumn{1}{c}{ WBRT } & Combination \\
2y RFS: 67\% & 2y RFS: $50 \%$ & 2y RFS: $78 \%$ \\
7y RFS: NA & 7y RFS: NA & 7y RFS: $78 \%$
\end{tabular}

Fig. 2 (See legend on next page.) 
(See figure on previous page.)

Fig. 2 OS in 43 PCNSL patients with a germinal center B cell (GCB) and a non-GCB DLBCL (a), OS and RFS in 43 PCNSL patients with CD10+ and CD10- (b) OS and RFS in 43 PCNSL patients with BCL2+ and BCL2-(c), OS and RFS in 43 PCNSL patients with BCL2+ in GCB and BCL2+ in non GCB (d), OS in 43 PCNSL patients treated with chemotherapy, WBRT and chemotherapy combined with WBRT (e), RFS in 43 PCNSL patients treated with chemotherapy, WBRT and chemotherapy combined with WBRT (f)

eclipsed by the high relapse rate in the latter group (Fig. 2). Although our patients did not receive a rituximab- or a thiotepa-based regimen, the treatment outcome was not different from those reported earlier [912]. The RFS and OS curves of our patients reached plateau after 2 years of initial treatment. Rate of RFS (70\%) was better than that of OS (40\%), because many patients, who didn't achieve a CR, had disease progression and died. Those achieving and sustaining a CR status within 2 years after treatment had a prolonged disease-free survival. Both RFS and OS rates were highest in those receiving a combined-modality therapy. However, this was mitigated by its $10 \%$ late neurotoxicity, which was unacceptable. Since one of the two cases had already received a lower radiation dose, together with no neurotoxicity in both single-modality therapy groups, the result suggested that modification of both modalities is needed to reduce this tragic complication. However, it must be done with a minimal or no sacrifice to the treatment efficacy. For the time being, this preliminary results suggested that a combined-modality therapy may be the best treatment option for PCNSL in countries with a limited access to the thiotepa-based regimen.

Multiple brain lesions were found in $63 \%$ of our patients, similar to those previously reported $[13,16]$. However, only $20-40 \%$ prevalence were also reported [17-21]. Large tumor ( $\geq 5 \mathrm{~cm}$ diameter) was found, particularly in patients with a solitary brain lesion, and had a worse CR and OS. Although the IELSG scoring system was not applicable due to lack of data on the CSF protein concentration, our study showed that an ECOG score $\leq 2$, a multiple brain lesions, a MTD $<5 \mathrm{~cm}$, a GCB subtype, a CD10+ were significantly associated with a prolonged OS. Interestingly, Han et al. [4] also reported that expression of $\mathrm{CD} 10$ protein was associated with a better OS in systemic DLBCL. Although MUM1 protein was co-expressed with $\mathrm{CD} 10+$ in the brain tissue of our $8 \mathrm{GCB}$ patients (CD10+/Bcl6+/MUM1+), the survival benefit was still seen, which has never been observed previously. Currently, the outcome of CD10+/ MUM1+ in systemic DLBCL patients are not yet known $[4,22-24]$. Furthermore, the Bcl6+ non-GCB tends to have a better RFS and OS than the Bcl6- counterpart. Triple negative CD10/BCL6/MUM1 (non GCB) was seen in 3 patients and, interestingly, they had a better RFS and OS than the MUM1+ one. Expression of Bcl2 protein was associated with a significantly worse OS in both the Bcl6+ and Bcl6- non-GCB group. The GCB subtype exhibited an excellent OS and RFS, even when coexpressed with $\mathrm{Bcl} 2$ protein. The median follow-up time of our patients was short, because many, who failed to achieve a CR, died early. Limitations of our study were a retrospective one, and a small number of patients.

Conclusions PCNSL had a dismal OS. Factors associated with a prolonged survival in this study were cell of origin of DLBCL (GCB subtype), lesion characteristics (MTD $<5 \mathrm{~cm}$, multiple brain lesions, multiple area of brain involvement), patients' performance status (ECOG score $\leq 2$ ) and treatment regimen (chemotherapy combined with WBRT).

\section{Abbreviations \\ DEL: Double-expressor lymphoma; DLBCL: Diffuse large B cell lymphoma; ECOG: Eastern co-operative oncology group; GCB: Germinal center B cell; MTD: Maximum tumor diameter; PCNSL: Primary central nervous system lymphoma}

\section{Acknowledgements \\ We would like to thank Mr. Waldemar Lillelund for his generous financial support, and to all patients.}

\section{Authors' contributions}

PN designed and carried out the experiment, analysed the data and wrote the manuscript. PB performed the histological examination of the brain and edited the manuscript. TS carried out the experiment and collected the data, $S P, P C, S P, K B, T P, P A, A U$ and SC carried out the experiment. VA edited the manuscript. All authors read and approved the final manuscript.

\section{Funding}

The study had no source of funding.

Availability of data and materials

Not applicable.

Ethics approval and consent to participate

This retrospective study was approved by the Local Ethics Committee on Human Rights related to research involving human subjects at Ramathibodi Hospital, Mahidol University.

Consent for publication

Not applicable.

\section{Competing interests}

The authors declare that they have no competing interests.

\section{Author details}

'Division of Hematology, Department of Medicine, Ramathibodi Hospital, Mahidol University, Bangkok, Thailand. ${ }^{2}$ Department of Pathology, Ramathibodi Hospital, Mahidol University, Bangkok, Thailand. ${ }^{3}$ Department of Medicine, ChakriNaruebodindra Medical Institute, Mahidol University, Bangkok, Thailand. 
Received: 28 February 2019 Accepted: 26 May 2019

Published online: 13 June 2019

\section{References}

1. Berglund $M$, Thunberg $U$, Amini RM, Book $M$, Roos $G$, Erlanson $M$, et al. Evaluation of immune-phenotype in diffuse large B-cell lymphoma and its impact on prognosis. Mod Pathol. 2005;18:1113-20.

2. Alizadeh AA, Eisen MB, Davis RE, Ma C, Lossos IS, Rosenwald A, et al. Distinct types of diffuse large B-cell lymphoma identified by gene expression profiling. Nature. 2000;403:503-11.

3. Rosenwald A, Wright G, Chan WC, Connors JM, Campo E, Fisher Rl, et al. The use of molecular profiling to predict survival after chemotherapy for diffuse large-B-cell lymphoma. N Engl J Med. 2002;346:1937-47.

4. Hans CP, Weisenburger DD, Greiner TC, Gascoyne RD, Delabie J, Ott G, et al. Confirmation of the molecular classification of diffuse large B-cell lymphoma by immuno-histochemistry using a tissue microarray. Blood. 2004;103:275-82.

5. Rubenstein $\mathrm{JL}$, Gupta NK, Mannis GN, Lamarre AK, Treseler P, et al. How treat CNS lymphomas. Blood. 2013;122:2318-30.

6. Ferreri AJ, Blay JY, Reni M, Pasini F, Spina M, Ambrosetti A, et al. Prognostic scoring system for primaryCNS lymphomas: the international extra-nodal lymphoma study group experience. J ClinOncol. 2003;21:266-72.

7. Abrey L, Yahalom J, De Angelis L. Treatment for primary CNS Iymphoma: the next step. J ClinOncol. 2000;18:3144-50.

8. Soussain C, Suzan F, Hoang-Xuan K, Cassoux N, Levy V, Azar N, et al. Results of intensive chemotherapy followed by hematopoietic stem-cell rescue in 22 patients with refractory or recurrent primary CNS lymphoma or intraocular lymphoma. J ClinOncol. 2001;19:742-9.

9. DeAngelis LM, Seiferheld W, Schold SC, Fisher B, Schultz CJ. Combination chemotherapy and radiotherapy for primary central nervous system lymphoma: radiation therapy oncology group study 93-10. J ClinOncol. 2002;20:4643-8.

10. Shah GD, Yahalom J, Correa DD, Lai RK, Raizer JJ, Schiff D, et al. Combined immuno-chemotherapy with reduced whole-brain radiotherapy for newly diagnosed primary CNS Iymphoma. J ClinOncol. 2007:25:4730-5.

11. Ferreri AJ, Dell'Oro S, Foppoli M, Bernardi M, Brandes AA, Tosoni A, et al. MATILDE regimen followed by radiotherapy is an active strategy against primary CNS Iymphoma. Neurology. 2006;66:1435-8.

12. Ferreri AJ, Reni M, Foppoli M, Martelli M, Pangalis GA, Frezzato M, et al. International Extra-nodal Lymphoma Study Group (IELSG)High-dose cytarabine plus high-dose methotrexate versus high-dose methotrexate alone in patients with primary CNS lymphoma: a randomized phase 2 trial. Lancet. 2009:374:1512-20.

13. Ferreri AJ, Cwynarski K, Pulczynski E, Fox CP, Schorb E, La Rosée P, et al. Whole-brain radiotherapy or autologous stem-cell transplantation as consolidation strategies after high-dose methotrexate-based chemoimmunotherapy in patients with primary CNS lymphoma: results of the second randomization of the international extra-nodal lymphoma study Group-32 phase 2 trial. Lancet Haematol. 2017;4:510-23.

14. Choi WW, Weisenburger DD, Greiner TC, Piris MA, Banham AH, Delabie J, et al. A new immuno-stain algorithm classifies diffuse large B-cell lymphoma into molecular subtypes with high accuracy. Clin Cancer Res. 2009;15(17): 5494-502

15. Swerdlow SH, Campo E, Pileri SA, Harris NL, Stein H, Siebert R, et al. The 2016 revision of the World Health Organization classification of lymphoid neoplasms. Blood. 2016;127:2375-90.

16. Hochberg FH, Miller DC. (1988). Primary central nervous system lymphoma. J Neurosurg. 1988;68(6):835-53

17. Haldorsen IS, Krakenes J, Krossnes BK, Mella O, Espeland A. CT and MR imaging features of primary central nervous system lymphoma in Norway, 1989-2003. Am J Neuroradiol. 2009;30:744-51.

18. Buhring U, Herrlinger U, Krings T, Thiex R, Weller M, Küker W. MRI features of primary central nervous system lymphomas at presentation. Neurology. 2011:57:393-6

19. Coulon A, Lafitte F, Hoang-Xuan K, Martin-Duverneuil N, Mokhtari K, Blustajn $\mathrm{J}$, et al. Radiographic findings in 37 cases of primary CNS lymphoma in immunocompetent patients. EurRadiol. 2002;12:329-40.

20. Küker W, Nägele T, Korfel A, Heckl S, Thiel E, Bamberg M, et al. Primary central nervous system lymphomas (PCNSL): MRI features at presentation in 100 patients. J Neuro-Oncol. 2005;72:169-77.
21. Fine HA, Mayer RJ. Primary central nervous system lymphoma. Ann Intern Med. 1993:119:1093-104

22. Camilleri-Broet S, Criniere E, Broet P, Delwail V, Mokhtari K, Moreau A, et al. A uniform activated B-cell-like immuno-phenotype might explain the poor prognosis of primary central nervous system lymphomas: analysis of 83 cases. Blood. 2006;107:190-6.

23. Lu TX, MiaoY WJZ, Gong QX, Liang JH, Wang Z, et al. The distinct clinical features and prognosis of the CD10+MUM1+ and CD10-BCI6-MUM1- diffuse large B-cell lymphoma. Sci Rep. 2016;6:1-10.

24. Kryachok I, Martynchyk AV, Filonenko K, Grabovoy AV, Antoniuk SA, Tytorenko I, et al. The predictive value of immuno-histochemical expression of BCl-2, BCl-6, MUM1, CD10 and CD30 in patients with diffuse large cell lymphoma. Ann Oncology. 2016;27(6):923.

\section{Publisher's Note}

Springer Nature remains neutral with regard to jurisdictional claims in published maps and institutional affiliations.
Ready to submit your research? Choose BMC and benefit from:

- fast, convenient online submission

- thorough peer review by experienced researchers in your field

- rapid publication on acceptance

- support for research data, including large and complex data types

- gold Open Access which fosters wider collaboration and increased citations

- maximum visibility for your research: over $100 \mathrm{M}$ website views per year

At $\mathrm{BMC}$, research is always in progress.

Learn more biomedcentral.com/submissions 